\title{
Ecos de uma tradição, a natureza morta no cinema de Andrei Tarkóvski
}

Driciele Glaucimara Custódio Ribeiro de Souza ${ }^{1}$

DOI 10.20396/eha.vil4.3449

\section{O cinema de Andrei Tarkóvski}

Com uma morte prematura aos 54 anos, Andrei Arsiénievitch Tarkóvski (1932-1986) é um cineasta que produziu relativamente pouco, sobretudo quando comparado a outros grandes realizadores do século XX como o inglês Alfred Hitchcock, que traz em seu currículo a direção de mais de cinquenta filmes, ou o estadunidense John Ford, este com uma lista que abrange mais de cem produções. Exilado em Paris, vítima de câncer, o diretor soviético deixou para a história do cinema um legado de apenas sete longas-metragens. Dotada de um tratamento estilístico muito singular, sua filmografia diverge de modo substancial da atividade cinematográfica de seus conterrâneos, que entre as décadas de 1960 e 1980, embora o relativo degelo político, ainda operava segundo a normatização estética imposta pelo Realismo socialista do período stalinista, quando a inclinação geral do cinema soviético era a de retratar o povo russo por meio de grandes narrativas heróicas com fortes tonalidades nacionalistas. Na contramão desta tendência, as películas de Andrei Tarkóvski seguem um impulso criativo diverso, tematicamente orientadas por um porvir destruidor e apocalíptico lembremos do cenário distópico de Stalker (1979) ou da ameaça bélica que paira sob o enredo de O sacrifício (Offret, 1986) -, antagônico ao passado e ao presente gloriosos ilustrados nas telas dos seus contemporâneos. Seguido pelos epítetos "poético", "místico" ou "transcendental", seu cinema com frequência foi interpretado como elitista, pouco didático ou instrutivo e, portanto, estranho aos ideais socialistas e revolucionários. Pouco partidário do patriotismo ideológico propagado nas produções de sua época, o trabalho de Tarkóvski condensa um panorama cultural multifacetado, conjugando diferentes registros artísticos - o teatro, a poesia, a música e a pintura - na confecção de um projeto estético singular.

Concisa, mas por isso não menos densa, sua filmografia reúne materiais produzidos em fronteiras históricas e territoriais muito distantes das soviéticas, engendrando uma espécie de rede

1 Mestranda no Programa de Pós-Craduação em Meios e Processos Audiovisuais, na Escola de Comunicações e Artes da Universidade de São Paulo. Bacharel em Letras (Russo) pela Faculdade de Filosofia, Letras e Ciências Humanas, na mesma universidade. 
conectiva por meio da qual circulam, se aproximam e se combinam conjuntos de imagens supostamente pouco conformes, como a iconografia ortodoxa medieval e o cultivado imaginário renascentista. Em Andrei Rubliov (1966), por exemplo, dedicado ao mais famoso pintor de ícones russo, o diálogo com a tradição pictórica ultrapassa a menção à obra do monge, revelando a forte influência das pinceladas de Pieter Bruegel, o Velho (c.1525-1569) no repertório imagético do cineasta. Pensamos aqui sobretudo no tratamento do motivo da vida campesina invernal, na miniaturização das figuras humanas em vastas paisagens, na subordinação do homem ao meio ambiente, bem como na fragilidade humana frente a grandeza natural, temas caros a Tarkóvski, para os quais a obra do holandês serve de frequente inspiração. Na ficção científica Solaris (1972), por outro lado, constatamos a harmoniosa convivência de distintas figuras artísticas como Andrea Mantegna (1431-1506) e Rembrandt Harmenszoon van Rijn (1606-1669); ao passo que em Nostalgia (Nostalghia, 1983), produção italiana do cineasta, vemos coexistir a solenidade da composição matemática de Piero della Francesca (1415-1492) e a poética romântica das ruínas de Caspar David Friedrich (1774-1840).

Nas películas de Tarkóvski, a pintura emerge de variadas maneiras. Ora como citação literal, inserida nos filmes como elemento diegético - na forma de quadros ou livros de arte manuseados pelas personagens -, ora incide na gênese da imagem cinematográfica, que toma a composição pictórica como premissa para arquitetura da mise en scène. Esta confluência, todavia, nem sempre se manifesta de modo patente e a cultura figurativa da qual o imaginário de Tarkóvski é herdeiro apresenta-se também de maneira um pouco mais rarefeita, exigindo do espectador especial atenção aos meandros formais da construção visual da narrativa, a fim de apreender esta sorrte de picturalidade difusa na filmografia do cineasta.

Pensar o aspecto formal do vocabulário cinematográfico tarkovskiano exige antes de tudo considerar a natureza perscrutadora de sua câmera, à qual é garantida considerável autonomia para experenciar e investigar os espaços que habita. Entre um plano geral e um close up, entre a extensão do horizonte e a fisionomia de um rosto, impulsionada pelo anseio de apreender o mundo em sua constituição elementar, a objetiva de Tarkóvski movimenta-se sem estabelecer hierarquias, criando, entre a vida terrestre em sua plenitude e a epiderme das coisas, retratos de objetos aos quais destina uma concentração comparável à depositada ao universo dramático das personagens. Daí a inegável plasticidade da cinematografia do soviético, repleta de superfícies que reclamam o sentido tátil do observador, não sendo raro nos depararmos em sua produção com imagens reduzidas à sua qualidade de pura textura, flertando, por vezes, com o abstracionismo. [fig. 01-03] Com efeito, quando confrontado com a história da pintura, este desejo tarkovskiano de explorar 

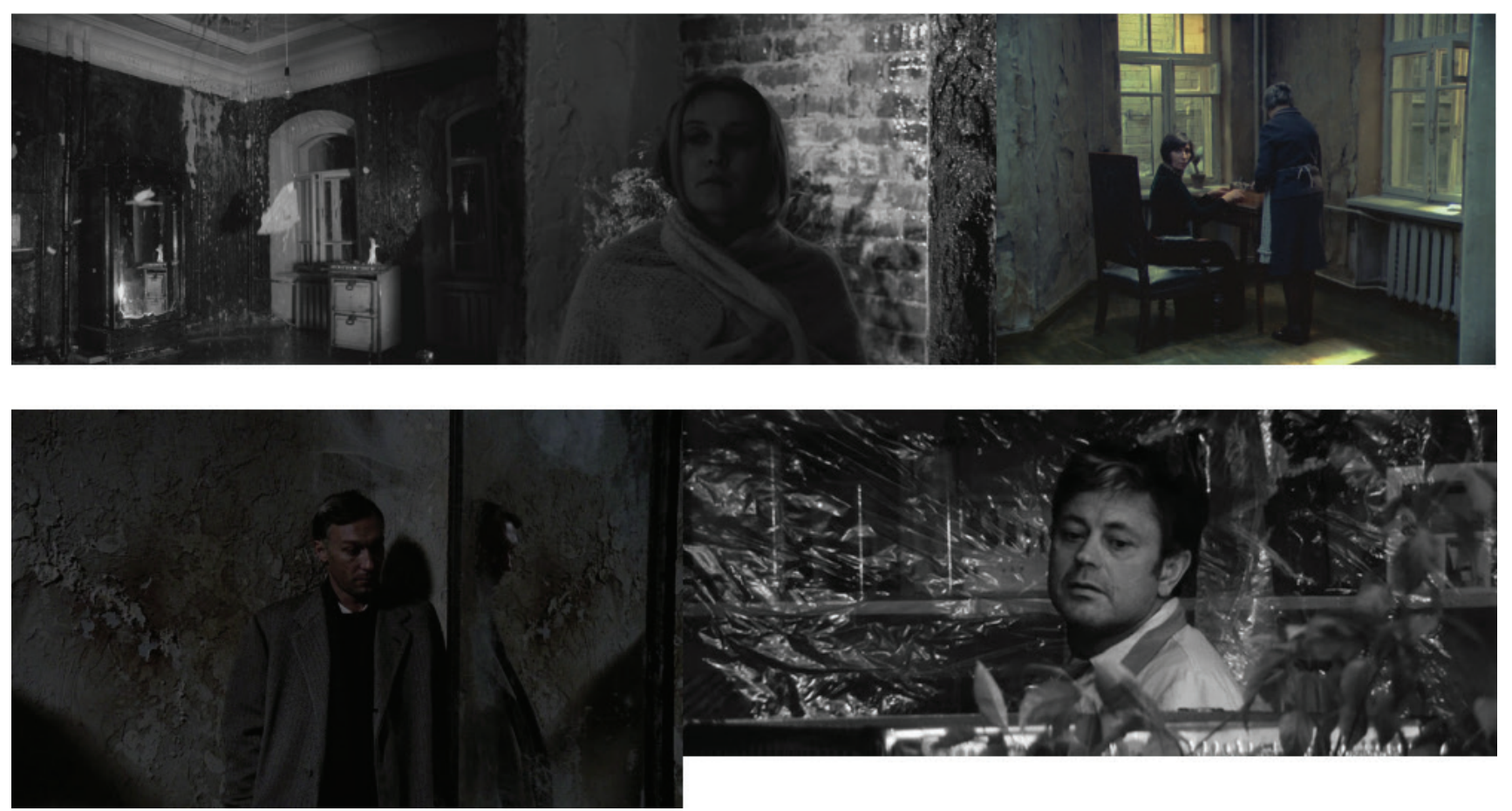

[Figura 01] frames de O espelho (acima); frames de Nostalgia e Solaris (abaixo)
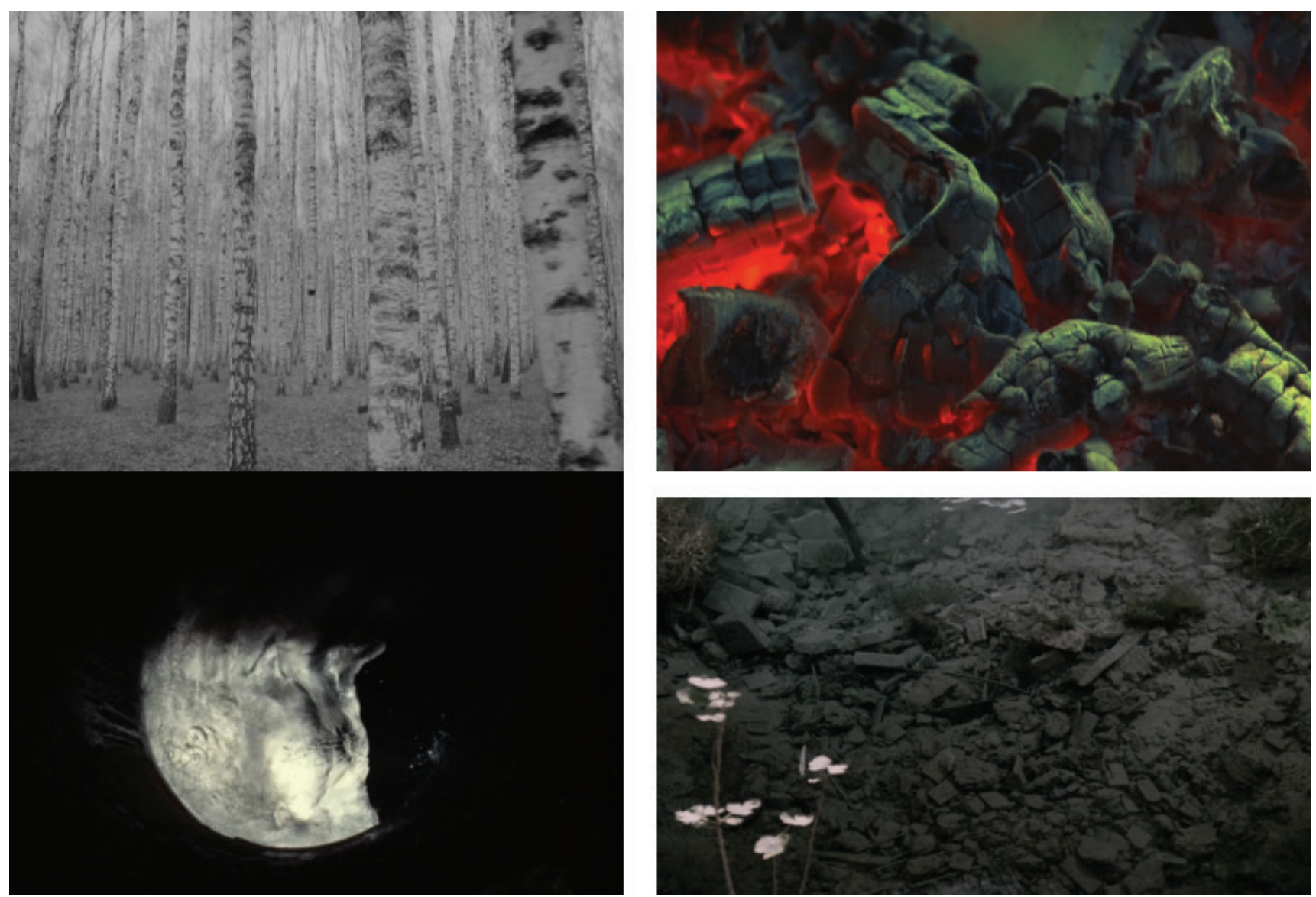

[Figura 02] frames de Infância de Ivan, O espelho, Stalker, Nostalgia 


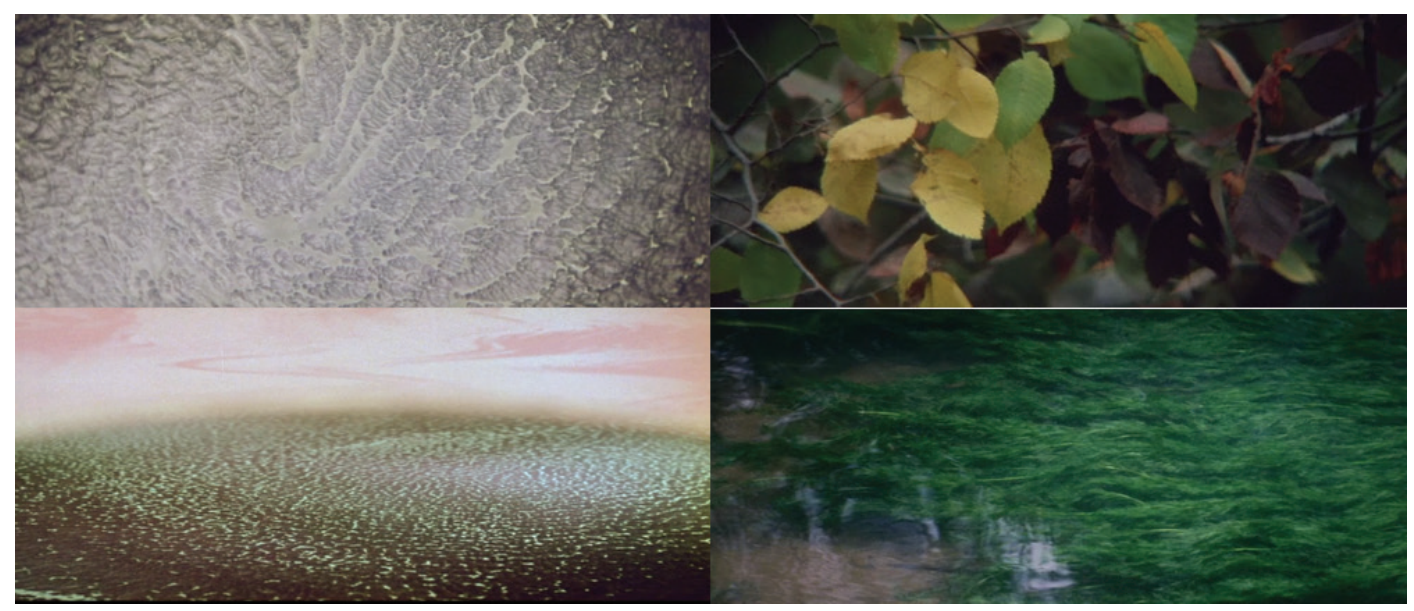

[Figura 03] frames de Solaris

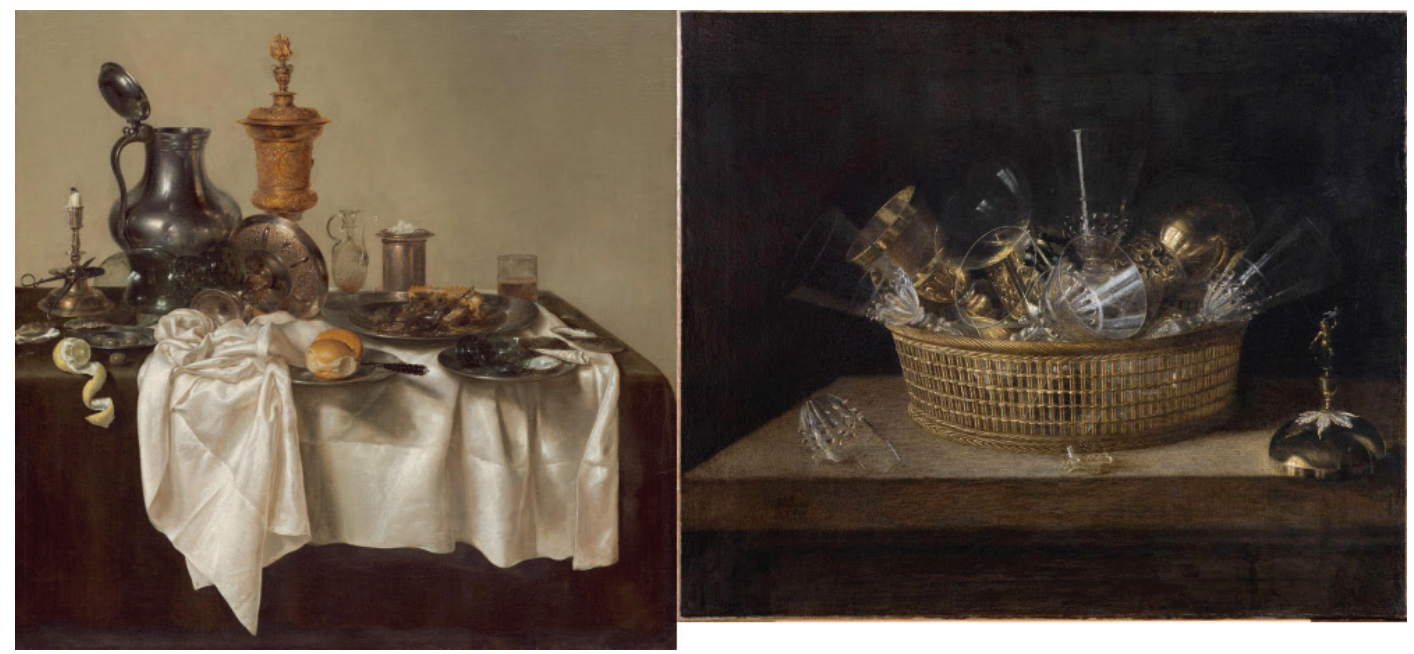

[Figura 04] Willem Claesz Heda, Banquet piece with ham, 1635.

Óleo sobre tela, 106, 7 X 111,1 cm, National Gallery of Art, Washington. Sébastien Stoskopff, Corbeille de verres, 1644 , óleo sobre tela, $52 \times 63 \mathrm{~cm}$, Museu de L'œuvre Notre-Dame, Estrasburgo

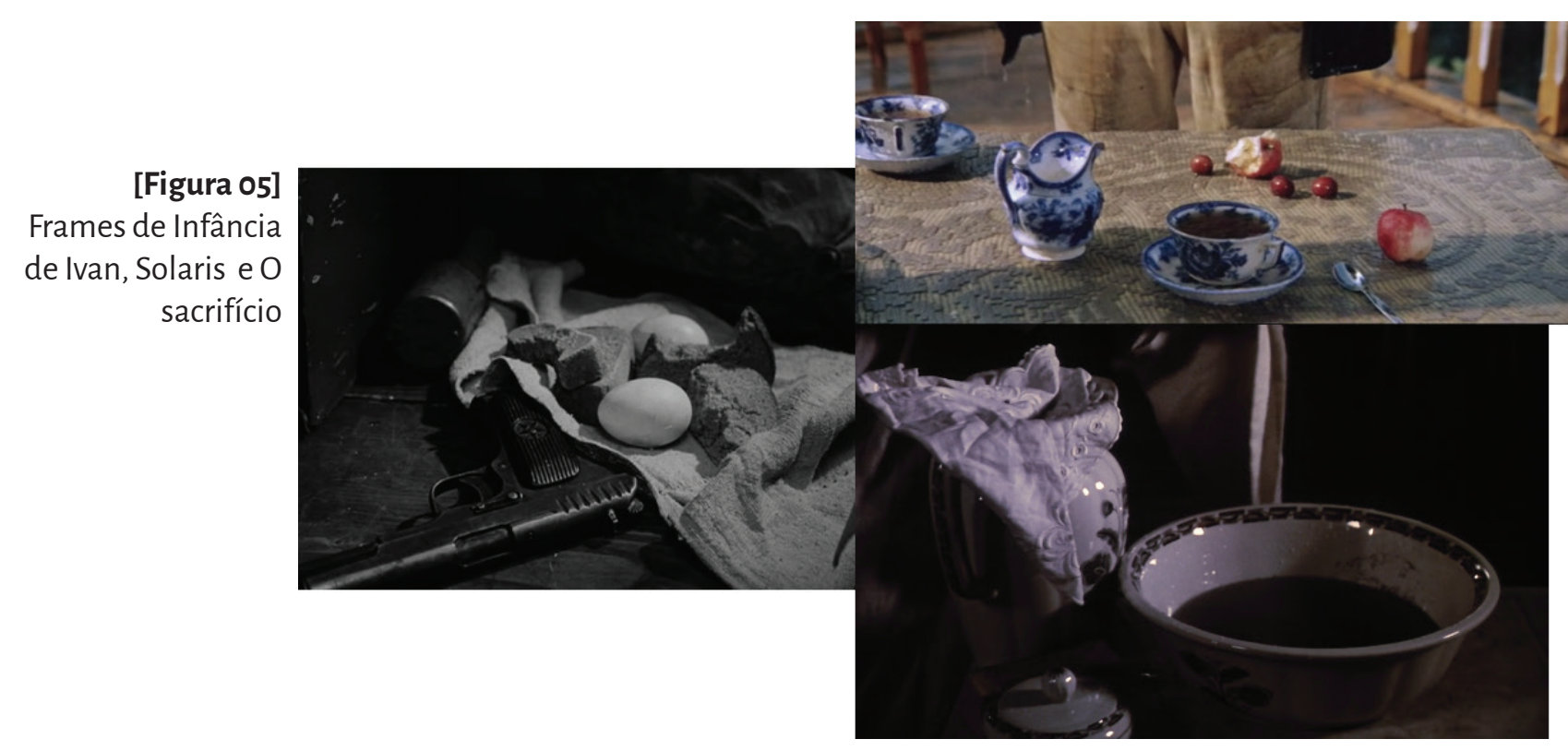


[Figura 06] frames de $O$ sacrifício (acima); frames de Solaris e $O$ espelho (abaixo)

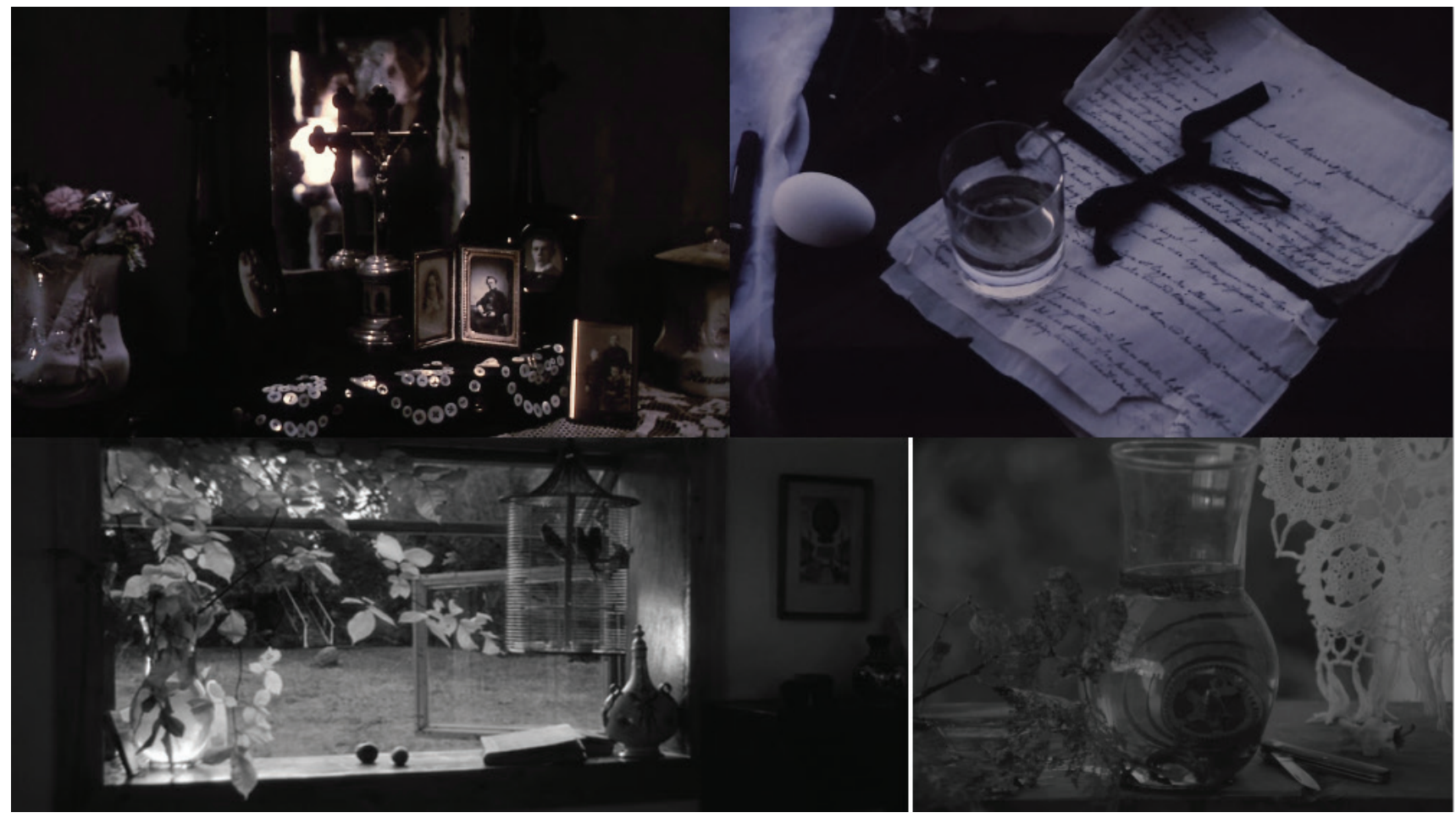

[Figura 07] frames de Nostalgia

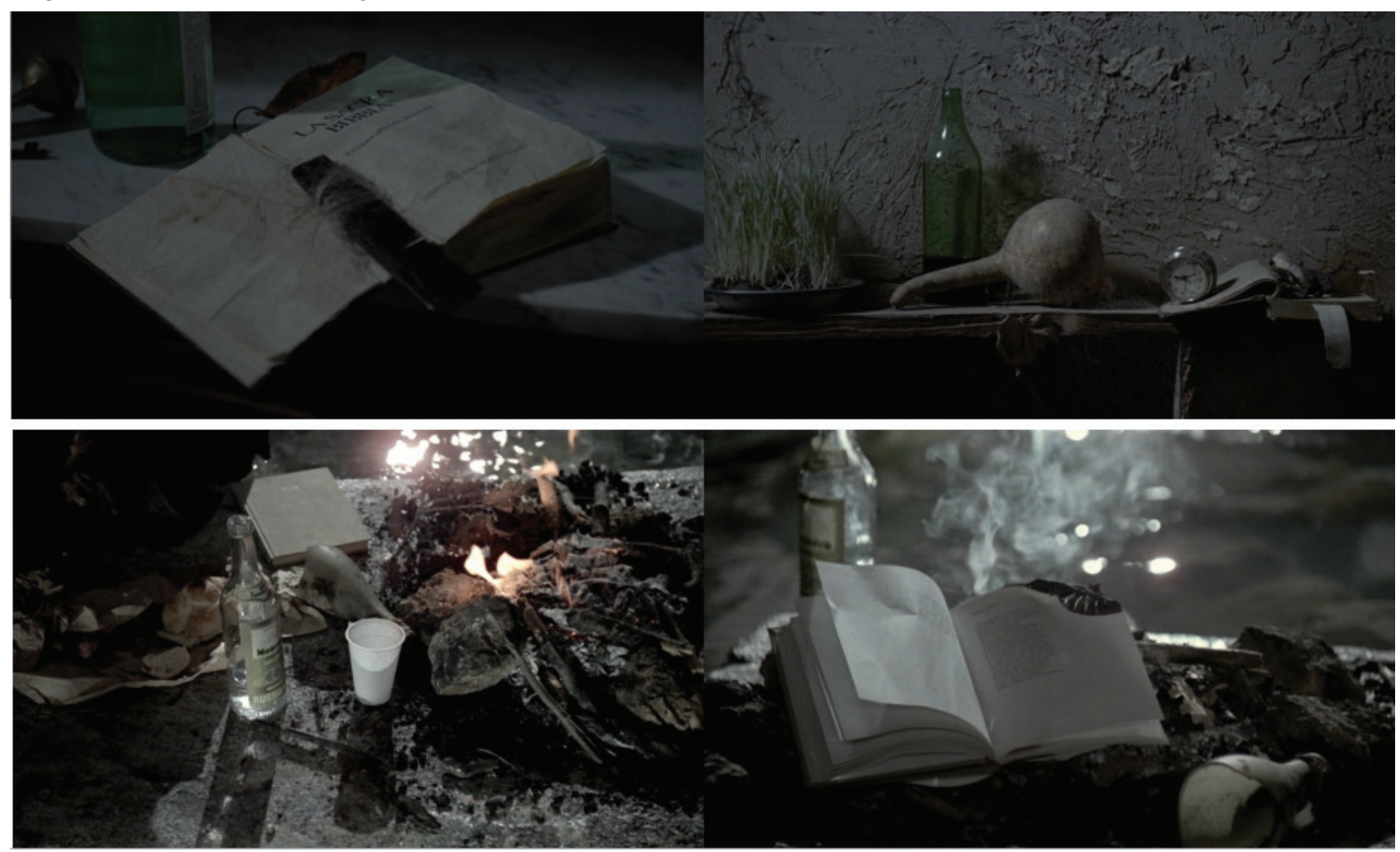




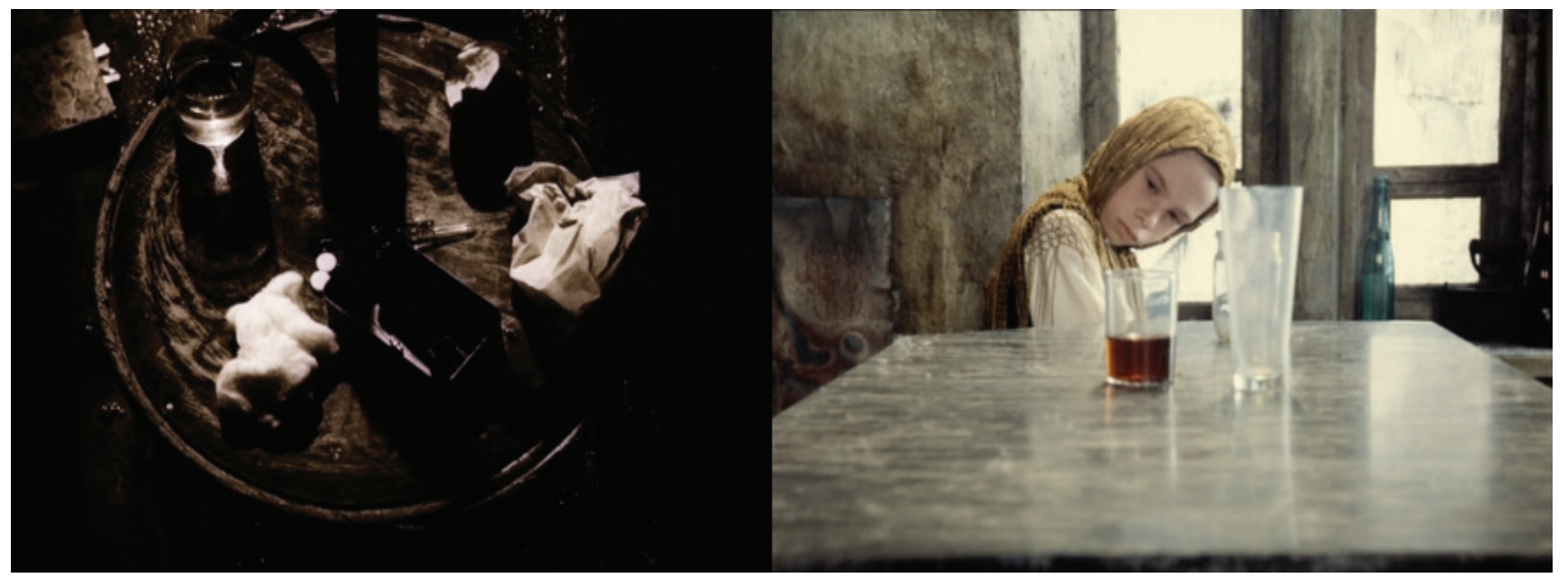

[Figura 08] frames de Stalker
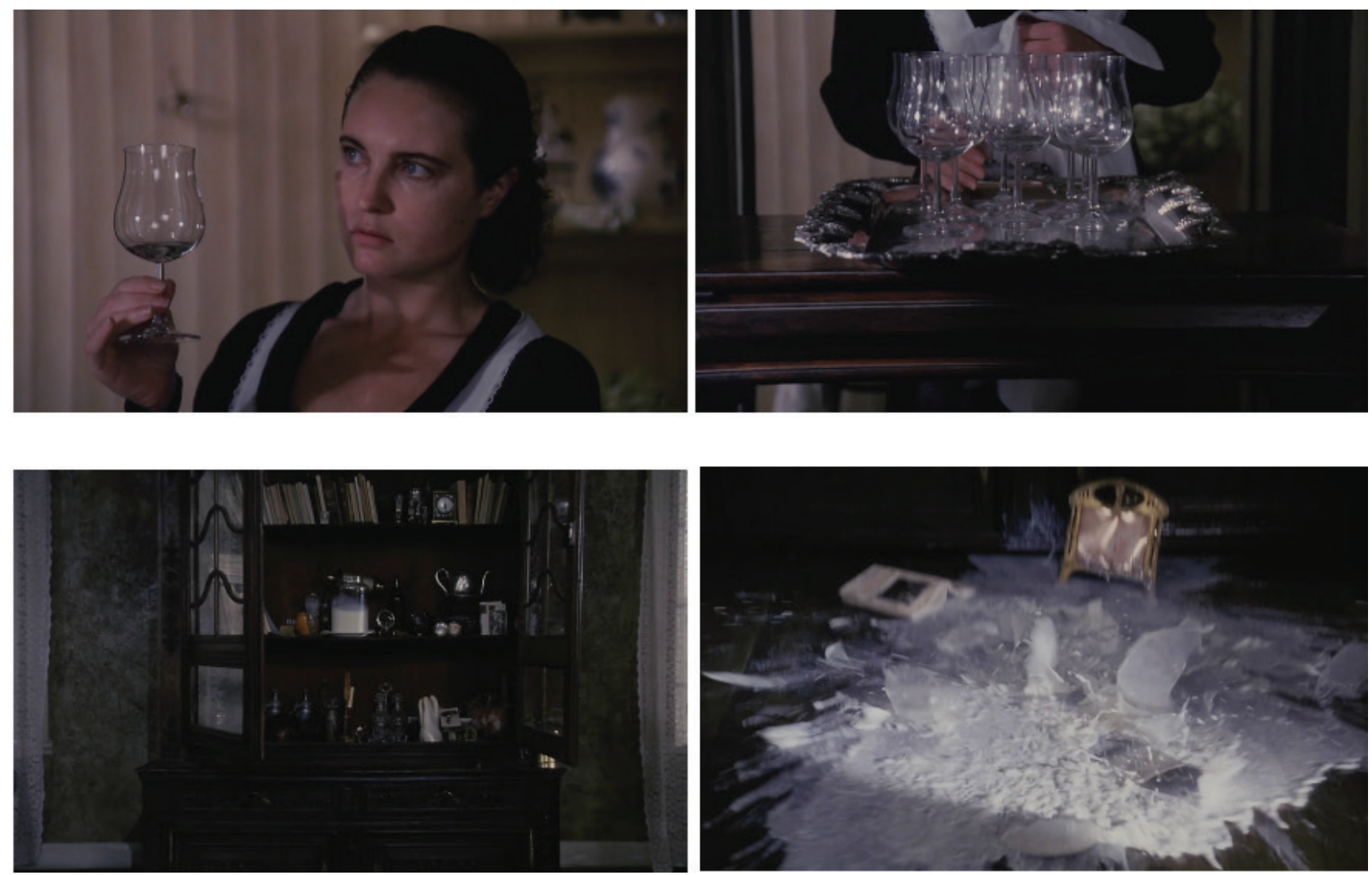

[Figura 09] frames de O sacrifício 
a materialidade das coisas, que vem acompanhado de uma postura de contemplação diante dos objetos, parece dar testemunho da relevância do gênero da natureza morta na constituição da cultura visual do diretor e, em consequência, em seu particular processo de elaboração da imagem fílmica.

\section{A natureza morta na pintura}

Na tradição iconográfica ocidental, o termo "natureza morta" é acompanhado de certas expectativas temáticas e estilísticas, povoando nosso imaginário com frutos e arranjos de flores de variadas espécies, pequenos insetos e singularidades do reino mineral, bem como instrumentos musicais, científicos e demais elementos associados à atividade intelectual e à erudição. [fig. 04] Na história da arte, entretanto, a convencional hierarquização estabelecida entre os gêneros pictóricos acabou por conduzir a natureza morta a um patamar inferior à pintura narrativa, ao retrato e à paisagem, retardando em consequência as pesquisas em torno do assunto. ${ }^{2}$

O polêmico debate acerca das origens da natureza morta, que começou a se desenvolver somente na década de 1950, é vasto e controverso, não cabendo a este breve estudo uma reconstituição exaustiva da discussão. Uma sumária exposição da discussão nos permite apontar, contudo, que embora não haja consenso sobre o momento ou o local preciso da aparição do gênero, os objetos tomados da realidade cotidiana sempre estiveram presentes na pintura, sendo sua representação uma prática que remonta à arte antiga. Alguns historiadores acreditam, por isso, ser possível traçar uma linha evolutiva, segundo a qual a natureza morta moderna consistiria em uma reelaboração aprimorada da pintura mural helenística - é a hipótese de Charles Sterling³ -, enquanto outros - é o caso de Combrich - julgam que a falta de documentação literária não permitiria nada além do que a comparação entre a pintura de natureza morta moderna e os motivos que sobrevivem em mosaicos clássicos e na arte decorativa. ${ }^{4}$ O que parece ser unânime entre os estudiosos, entretanto, é a opinião de que o ambiente cultural do humanismo renascentista tenha favorecido a decisão intelectual de transformar a natureza morta em um gênero independente.

É nesse cenário que em meados do Quatrocentos vemos ressurgir o interesse pictórico pelas

\footnotetext{
2 VERSHAEELL, Bart. “'́espace pictural de la nature morte”. In: Essais sur les genres en peinture: Nature morte, portrait, paysage. Tradução de Daniel Cunin. Belgica: La Lettre Volée, 2007. (Collection Essais) p. 11

3 STERLING, Charles. La nature morte de l'antiquité à nos jours. Paris: Tisné, 1952.

4 COMBRICH, Ernest H. "Tradição e expressão na Natureza-morta Ocidental". In: Meditações sobre um cavalinho de pau. Tradução Geraldo Cerson de Souza. São Paulo: Edusp, 1999. p. 103
} 
coisas inanimadas, sendo as cenas religiosas, tais como o episódio canônico da Anunciação ou a vida dos santos devotos, argumento oportuno para a representação de interiores domésticos dotados de objetos. Nas cenas que retratam o colóquio angelical, por exemplo, é comum encontrarmos vasos de flores e livros de oração que aludem à pureza e à religiosidade da futura mãe de Cristo, enquanto que nas células dos santos estudiosos, a profusão de livros e de instrumentos de escrita figuram com destacada importância, atestando a sagrada erudição destes homens de fé. Cada vez mais isolados do resto da composição, estes acessórios, que mais tarde se tornaram típicos da natureza morta, tendem a atrair a atenção visual do observador e, de fato, quando fazemos uma decupagem fotográfica dessas composições, descobrimos nelas indícios prototípicos do gênero.

Alvo de interesse desde a Antiguidade, é, no entanto, apenas apenas no século XVII que o mundo inanimado alcança autonomia na pintura, quando torna-se argumento da primeira composição de cavalete exclusivamente dedicada ao tema. Não obstante a disposição em separar os objetos de seu contexto iconográfico, bem como o surgimento de gêneros seculares derivem da nova atitude artística oriunda da Renascença italiana, são os Países do Norte dos Alpes, porém, que fazem do tema a sua especialidade. "É o tempo", nos lembra Sterling, "dos gabinetes de curiosidades, das grandes navegações oceânicas, do enriquecimento burguês pelo comércio nas Índias"s, e a pintura de natureza morta, nessa conjuntura, testemunha a emergência de uma curiosidade enciclopédica, o despontar da atividade colecionadora, da ilustração científica ${ }^{6}$, fornecendo ainda indícios de como o fenômeno da fartura foi visto e entendido sob a ótica dos holandeses. Em suma, segundo Brysson, a natureza morta holandesa configura a estreita relação entre a afluente sociedade daquele momento e suas posses materiais, daí a compreensão deste gênero pictórico como reflexo das transformações sociais desencadeadas pelo acúmulo de capital. ${ }^{7}$

Mas o fascínio pelas coisas inanimadas porta ainda outras implicações, evidenciando a sobrevivência de uma sensibilidade herdada do pensamento medieval. ${ }^{8}$ Em uma mentalidade essencialmente religiosa, o interesse pela representação dos objetos só se justifica a partir do momento em que a vida terrena e a realidade cotidiana são integradas à sua concepção cristã de universo como indicadores da onipresença do divino. ${ }^{9}$ Da ideia de que as coisas comportam uma existência

\footnotetext{
5 STERLING, op. cit., p. 42, livre tradução

6 VERSHAEELL, op. cit. p. 15

7 BRYSON, Norman. Looking at the overlooked: Four essays on still life painting. Londres: Reaktion Books, 1990. (Essays in Art \& Culture) p. 103-104

8 LOZANO OCAMPO, Amaro. "Le langage perdu des choses: une histoire de la nature morte". Lettre du séminaire, 88. 2015. Disponível em:

<<http://www.sciencespo.fr/artsetsocietes/fr/archives/434>>

9 STERLING, op. cit., p. 16
} 
transcendente, dissimulada sobre a matéria sensível, decorre que a representação dos objetos acaba por se impregnar de uma profunda significação religiosa e por isso a pintura de natureza morta deste período, composta por um repertório demasiado simbólico, denotar uma preocupação de fundo essencialmente espiritual. Assim, flores e alimentos apodrecidos; cristais, bolhas de sabão e cordas rompidas; relógios, ampulhetas e outros instrumentos científicos figuram nessas composições como imagem da fatal fuga do tempo e da corruptibilidade da matéria, lembrando ao homem o dever de se humilhar diante da soberania de Deus.

\section{Ecos de uma tradição}

Nas películas do soviético, igualmente ocupadas de uma comunhão com o divino, os planos que se reportam ao universo simbólico da natureza morta são abundantes: são mesas servidas com frutas, louças, vidros e porcelanas, ou ainda reuniões de livros, fragmentos de calendários, moedas, velas, candelabros e engrenagens, todos motivos comuns ao antigo gênero pictórico. [fig. 05-07] Assim, embora voltado ao sublime, o cinema de Tarkóvski demonstra uma atenção excerbada ao universo dos objetos, à composição da matéria e, em consequência, à concretude da imagem fílmica, revelando uma flagrante preocupação com a dimensão tangível do mundo.

Esta atenção destinada às coisas, no entanto, não é gratuita; ela intenciona muitas vezes revelar a ação de forças invisíveis sobre as coisas inanimadas, de maneira a despertar no espectador um verdadeiro sentimento de perturbação. A fim de alcançar um efeito estético desnorteante, Tarkóvski amiúde apresenta estas forças como fenômenos momentaneamente inexplicáveis, dando antes a ver a consequência do que a causa da ação. ${ }^{10}$ Na sequência inicial de Stalker, por exemplo, assistimos a um grupo de objetos repentinamente tremularem sobre a mesinha de cabeceira do protagonista, para apenas após alguns segundos de estupefação, o som em off de uma locomotiva sugerir a motivação para o ocorrido. Um evento semelhante sucede-se ainda na cena final do mesmo filme, quando, sob o olhar da filha de Stalker, alguns copos de vidro, sem qualquer impulso externo visível, deslizam sobre a mesa em direção ao observador. O acontecimento, extraordinariamente justificado por uma atividade telecinética da menina, é, no entanto, mais uma vez, associado à partida do trem no fora de campo, elemento diegético que não anula por completo, entretanto, 
a ambiguidade visual previamente conferida ao episódio. [fig. 08]

A fim de melhor ilustrar a relação entre a busca de Tarkóvski por significações de ordem metafísica e as alusões à natureza morta em seu cinema, examinemos uma sequência de $O$ sacrifício. O filme narra a história de Aleksander, um intelectual que, diante de uma ameaça bélica global, sacrifica seus bens materiais em nome da paz e do bem-estar de sua família. A sequência que aqui nos interessa diz respeito precisamente ao momento em que a catástofre é instaurada na narrativa. Detenhamo-nos por um instante sobre a cena para que uma sua breve descrição nos permita traçar algumas hipóteses e reflexões.

Julia, a empregada da família, em close up, tem em mãos uma taça. Ouvimos o tilintar de vidraria. A câmera opera uma panorâmica vertical para baixo, deslocando-se do rosto atônito da moça para o conjunto de taças a trepidar sobre uma bandeja. Em crescendo, um som grave e abafado leva-nos para a próxima tomada. Na sala de estar, objetos metálicos caem de uma estante semi aberta e o som advindo do fora de campo insinua o vôo inexplicável de caças sobre a casa. Assustados, tentando entender o incidente, os personagens cruzam apressados o ambiente de um lado ao outro, ao que a câmera acompanha com rápidos movimentos panorâmicos. Em um ligeiro travelling in, a objetiva aproxima-se da estante repleta de livros e louças, ao passo que o zumbido dos aviões torna-se cada vez mais estrondoso. Um corte seco, quase imperceptível. O corpo de Marta, filha de Aleksander, atravessa o quadro, interpondo-se por um instante entre o móvel e a câmera, quando uma grande jarra de leite, pousada sobre a estante, não resiste à vigorosa vibração, e estilhaça-se no chão. [fig. 09]

Tal como em Stalker, as taças aqui começam a tilintar sem que possamos identificar com clareza a causa de sua perturbação. A deliberada decalagem entre a movimentação da vidraria e o som em off, que tarda alguns segundos em anunciar o bombardeio, deixa em suspenso por um breve instante a causa do evento, provocando no espectador um sentimento momentâneo de confusão. De modo que, a despeito do pretexto diegético, prevalece na cena seu imediato efeito de estranhamento e indeterminação, como se, obstinado em desvendar a presença incorpórea de algo fantástico ou mesmo divino, Tarkóvski apostasse em desafiar nossa percepção visual por meio de fenômenos que parecem prescindir as leis naturais do universo sensível. Se retrocedemos alguns minutos na sequência, lembramos que Otto, o carteiro, é de fato acometido por uma força invisível, dessa vez silenciosa, que o lança no chão e a qual ele atribui ao toque de um anjo maligno. A ideia de ser visitado por um mensageiro funesto pouco convence aos personagens - e também a nós espectadores incrédulos -, mas o tilintar, a princípio inexplicável da vidraria, põe à prova nossa credu- 
lidade nos limites físicos da matéria, dando mostras de que o filme age no sentido de validar em retrospecto o fenômeno angélico espetacular, que até então nos parecia pouco provável. De fato, enquanto a racionalidade nos impede de enxergar para além da realidade sensível, a inexplicada animação das coisas no plano, por sua vez, - ainda que se trate de um animismo provisoriamente injustificado - nos incita a refletir, à exemplo da pintura de natureza morta, sobre a condição humana, sobre a fragilidade da existência, sobre a efemeridade da vida terrena, enfim, sobre a destruição da matéria.

\section{Considerações finais}

Singular por sua natureza essencialmente contemplativa, o cinema de Tarkóvski não dissimula sua inclinação para o sagrado, e em consequência disso, para o impal pável e o invisível. No entanto, como demonstra sua filmografia, o processo criativo do cineasta é orientado pelo anseio em capturar e sublinhar como o etéreo manifesta-se visualmente no mundo tangível, ambição que se revela na especial atenção por ele destinada à composição da imagem fílmica. Por esse motivo, julgamos que a relação de Andrei Tarkóvski com a natureza morta não se limita a mimetizar a retórica visual na qual ele se inspira, mas no fato de seu cinema partilhar com essa tradição pictórica a tentativa de comunicar o insondável por meio da realidade sensível. 


\section{Referências bibliográficas}

AUMONT, Jacques. "Vanités (Migrations, 2)". Cinémathèque, n. 16, outono 1999.

BETTINELLI, Philippe. "Plonger les choses les plus familières dans une ambiance irrationnelle: les objets dans le

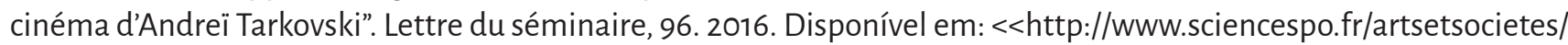
fr/archives/2652>>

BRYSON, Norman. Looking at the overlooked: Four essays on still life painting. Londres: Reaktion Books, 1990. (Essays in Art \& Culture)

CLAUDEL, Paul. "Introduction à la peinture hollandaise". In: L'oeil écoute. Gallimard, 1964.

COMBRICH, Ernest H. "Tradição e expressão na Natureza-morta Ocidental". In: Meditações sobre um cavalinho de pau. Tradução Geraldo Gerson de Souza. São Paulo: Edusp, 1999.

LOZANO OCAMPO, Amaro. "Le langage perdu des choses: une histoire de la nature morte". Lettre du séminaire, 88. 2015. Disponivel em: <<http://www.sciencespo.fr/artsetsocietes/fr/archives/434>>

STERLING, Charles. La nature morte de l'antiquité à nos jours. Paris: Tisné, 1952.

VECA, Alberto. Vanitas: Il simbolismo del tempo. Itália: Galleria Lorenzelli, 1981.

VERSHAEELL, Bart. "L'espace pictural de la nature morte". In: Essais sur les genres en peinture: Nature morte, portrait, paysage. Tradução de Daniel Cunin. Belgica: La Lettre Volée, 2007. (Collection Essais)

\section{Filmografia}

IVANOVO detstvo (Infância de Ivan). Direção de Andrei Tarkovski. URSS/Ucrânia: Mosfilm, Trete Tvorcheskoe Obediente, 1962. 95 min., son., P\&B. Formato: 35mm.

ANDREI Rublev. Direção de Andrei Tarkovski. URSS: Mosfilm, 1966. 205 min., son., P\&B/Color. Formato: 35mm. SOLIARIS (Solaris). Direção de Andrei Tarkovski. URSS: Mosfilm, 1971. 167 min., son., P\&B/Color. Formato: 35mm. ZERKALO (O espelho). Direção de Andrei Tarkovski. URSS: Mosfilm, 1975. 107 min., son., P\&B. Formato: 35mm. STALKER. Direção de Andrei Tarkovski. URSS: Mosfilm, Trete Tvorcheskoe Obediente, 1979. 162 min., son., P\&B/Color. Formato: $35 \mathrm{~mm}$.

NOSTALCHIA (Nostalgia). Direção de Andrei Tarkovski. Itália/URSS: Rai 2, Sovinfilm, 1983. 125 min., son., P\&B/Color. Formato: $35 \mathrm{~mm}$.

OFFRET (O sacrifício). Direção de Andrei Tarkovski. Suécia/França/Reino Unido: Svenska Filminstitutet, Argos Films, 1986. 149 min., son, Color. Formato: $35 \mathrm{~mm}$. 